症例

Frey の手術が有効であった膵性腹水の 1 例

若草第一病院外科

浦田尚巳浅川隆廣岡慎治

近畿大学第 2 外科（主任：大柳治正教授）

今 野 元 博 大柳 治 正

脺性腹水は良性膵疾患に起因寸る大量かつ慢性的な腹水貯留で，その多くは慢性脺炎 に随伴した内膵液㾇の形成によって生ずると考えられている. 今回われわれはアルコー ル性慢性膵炎に合併した膵性腹水の 1 例を経験した。症例は62歳男性で, 高アミラーゼ, 高蛋白の大量の腹水を認めた。内視鏡的逆行性胆管膵管造影 (ERCP)にて仮性襄胞と考 えられる部分と,引き続き施行した腹部コンピューター断層撮影 (CT)にて, 造影剂の 腹腔内漏出を認めたので, 膀性腹水と診断した，高力ロリ一輸液や腹水穿刺等保存的治 療に奏功せす，Frey の手術を施行し，良好な結果を得られたので報告する.

索引用語：膵性腹水, Frey の手術

\section{緒 言}

膵性腹水は膵の良性疾患や腹部外傷後において脺管 または仮性犦胞から直接，腹腔内に膵液が漏出するこ とに起因し，急性脺炎時に見られる反応性の腹水とは 区別される比較的稀な病態である ${ }^{1)-3)}$. 脺性腹水の治 療として,内科的には急性膵炎に準じた治療が行われ， 内科的治療が無効な場合には外科的に膵切除やドレ ナージ術などが施行される゙34!．今回われわれは慢性脺 炎に伴う膵性腹水に対し，Freyの手術 ${ }^{\text {' }}$ を施行し良好 な結果が得られたので報告する。

\section{症例}

患者：62歳, 男性.

主訴：腹満, 食欲低下。

既往歴：特記すべきことなし。

飲酒歴：ウイスキー，コップ 2 杯/日×30年.

現病歴：平成 2 年頃より慢性脺炎の診断のもとに近 医通院中であったが，平成 7 年 3 月中頃より，腹満， 食欲低下あり，左足にも浮腫あり，精査目的にて当院 受診し入院となる。

入院時現症：身長 $165 \mathrm{~cm}$ ，体重 $48 \mathrm{~kg}$ ，血厌 $150 / 90$ $\mathrm{mmHg}$, 脈拍 80 回/分, 体温 $36.7^{\circ} \mathrm{C}$, 栄責状態不良, 腹 囲 $85 \mathrm{~cm}$, 皮厗乾燥, 結膜に貧血なし, 心肺に異常なし， 腹部膨満あるも腹痛, 腹部圧痛, 嘔気, 嘔吐, 脂肪性 下痢なし。肝脾触知せず。

1996年 2 月 7 日受付 1997 年 3 月11日採用
検査所見（表 1)：表に示したごとく膵性酵素の著明 な上昇を認めた。

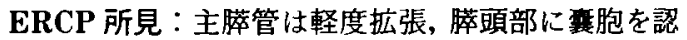
める、膵石を疑わせる所見は認められなかった(図 1).

腹部 CT 所見：門脈の後面に仮性萁胞をみとめ(図 2)，その䧶胞は ERCPにて造影され，さらに造影郕は

表 1 血液検查テータ

\begin{tabular}{|c|c|c|c|}
\hline WBC & $7,100 / \mu 1$ & T. cho & $81 \mathrm{mg} / \mathrm{dl}$ \\
\hline $\mathrm{RBC}$ & $442 / \mu 1$ & TG & $76 \mathrm{mg} / \mathrm{dl}$ \\
\hline $\mathrm{Hb}$ & $9.1 \mathrm{~g} / \mathrm{dl}$ & $\mathrm{CRP}$ & $1.4 \mathrm{mg} / \mathrm{dl}$ \\
\hline $\mathrm{Ht}$ & $32.0 \%$ & GOT & $42 \mathrm{IU} / \mathrm{l}$ \\
\hline Plt & $57.5 / \mu \mathrm{l}$ & GPT & $15 \mathrm{IU} / l$ \\
\hline $\mathrm{Na}$ & $142 \mathrm{mEq} / \mathrm{l}$ & ALP & $216 \mathrm{IU} / l$ \\
\hline K & $4.0 \mathrm{mEq} / l$ & $\mathrm{LDH}$ & $490 \mathrm{IU} / l$ \\
\hline C) & $105 \mathrm{mEq} / \mathrm{l}$ & $\gamma \cdot \mathrm{GTP}$ & $23 \mathrm{IU} / l$ \\
\hline $\mathrm{Ca}$ & $7.5 \mathrm{mEq} / l$ & ChE & $0.31 \mathrm{Aph}$ \\
\hline BUN & $12 \mathrm{mg} / \mathrm{dl}$ & a-Amy & $4,075 \mathrm{IU} / l$ \\
\hline Cre & $0.7 \mathrm{mg} / \mathrm{dl}$ & s-type & $0 \%$ \\
\hline T.P & $6.4 \mathrm{~g} / \mathrm{dl}$ & p-type & $100 \%$ \\
\hline Alb & $3.1 \mathrm{~g} / \mathrm{dl}$ & $\mathrm{u} \cdot \mathrm{Amy}$ & $37.840 \mathrm{IU} / l$ \\
\hline CEA & $\begin{array}{l}1.1 \mathrm{ng} / \mathrm{ml} \\
(5.0 \text { 以下 })\end{array}$ & トリプシン & $\begin{array}{c}14,400 \mathrm{ng} / \mathrm{ml} \\
(10 \sim 500)\end{array}$ \\
\hline CA19-9 & $\begin{array}{c}16 \mathrm{U} / \mathrm{ml} \\
(130 \sim 400)\end{array}$ & エラスターゼ I & $\begin{array}{l}2,370 \mathrm{ng} / \mathrm{ml} \\
(400 \text { 以下 })\end{array}$ \\
\hline PSTI & $\begin{array}{l}50.8 \mathrm{ng} / \mathrm{ml} \\
(5.9 \sim 22.7)\end{array}$ & PLA2 & $\begin{array}{l}3,830 \mathrm{ng} / \mathrm{dl} \\
(130 \sim 400)\end{array}$ \\
\hline リパーゼ & $\begin{array}{l}1.250 \mathrm{U} / l \\
(36 \sim 161)\end{array}$ & & \\
\hline
\end{tabular}




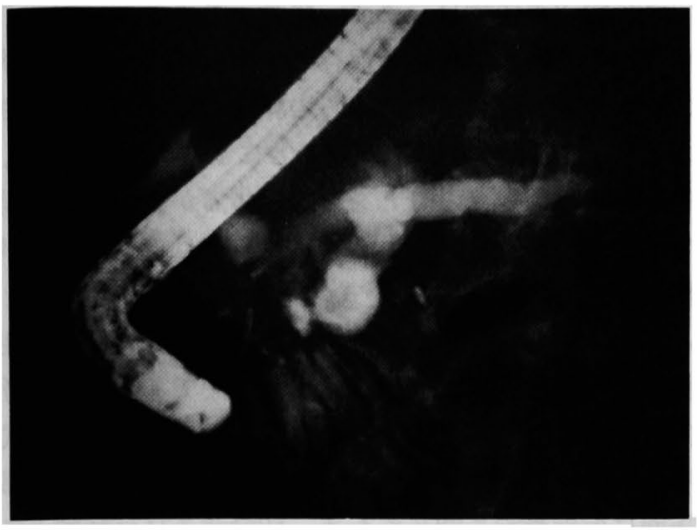

図 1 ERCP : 主膵管は拡張し, 膵頭部に仮性裹胞を 認める.

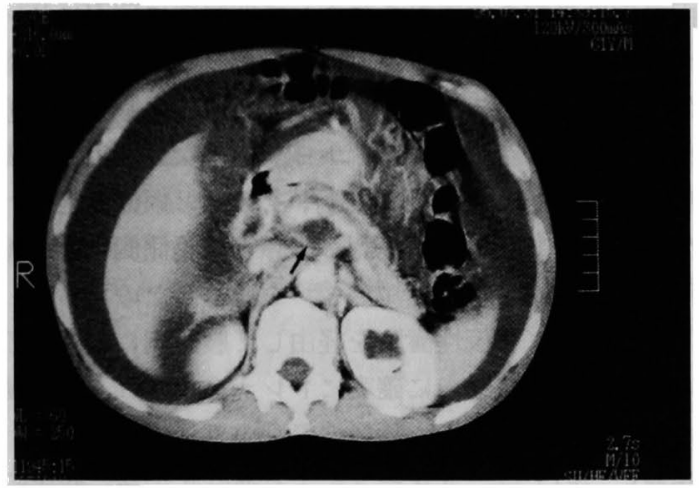

図 2 腹部 CT : 拡張した主膵管と膵頭部後面の仮性 蛪胞（矢印）を認める.

\section{モリソン窩に流出した（図 3 ).}

腹水所見 (表 2 )：表のごとく高アミラーゼ，高蛋白 の腹水であった。

入院後の経過：約 5 週間の絶食, 高カロリー輸液, 数回の腹水穿刺を試みるも効果は認められなかった.

手術所見：大量の腹水を認め,腹壁には膿苔の付着, 腸管表面には炎症性の発赤を認めた。 Kocher の授動 術を施行し, 膵頭後面の膵液漏出部と思小れる仮性桽 胞壁を破りその内腔に到達した。次に膵管を長軸方向 に切開し, 脺管内腔と仮性銮胞内腔との十分な交通を 確立するために，膵頭部にて coring-out を施行（図 $4)$ ，膵管空腸側々吻合を行った。

術後 ERCP 所見：造影剤は空腸に流出, 腹空内への 漏出は認めなかった。

術後経過：経過は良好で, 術後10日目より食事を再

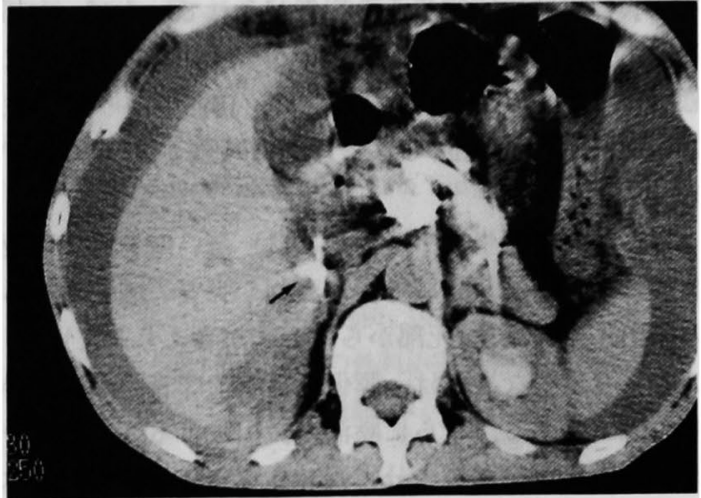

図 3 腹部 CT (ERCP 後)：造影された主膵管および 仮性霟胞, モリソン窝に漏出した造影剤（矢印）を 認める。

\section{表 2 腹水検査データ}

\begin{tabular}{|c|c|c|c|}
\hline 性状 & 赤血球混入 & タンパク & $3.5 \mathrm{~g} / \mathrm{dl}$ \\
\hline 比重 & 1.027 & アミラーゼ & $32,928 \mathrm{IU} / l$ \\
\hline リバルタ反応 & + & \multicolumn{2}{|c|}{ ホスホリパーゼ A 2} \\
\hline 細胞数 & $475 / \mathrm{mm}^{3}$ & & $63,500 \mathrm{ng} / \mathrm{ml}$ \\
\hline 好中球 & $2 \%$ & エラスターゼ I & $76,200 \mathrm{ng} / \mathrm{dl}$ \\
\hline リンパ球 & $88 \%$ & PSTI & $17.7 \mathrm{ng} / \mathrm{ml}$ \\
\hline 組織球 & $10 \%$ & トリプシン 31 & 500 以上 $\mathrm{ng} / \mathrm{ml}$ \\
\hline 中皮細胞 & + & 細胞診 & 陰性 \\
\hline
\end{tabular}

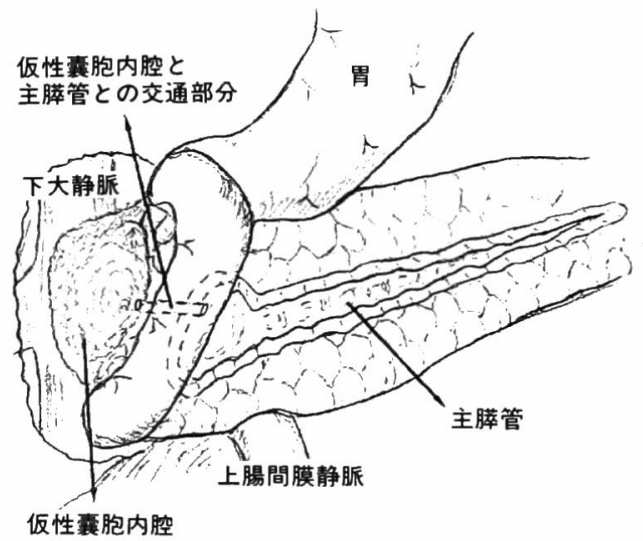

図 4 術中所見のシェーマ:脺頭部にて coring-out を施行することによって膵管内腔と仮性襄胞内腔と の間に十分な交通が確立できた。

開，ドレーンは術後21日目に抜去し, 腹水の再貯留も なく術後31日目には退院した。現在外来通院中である.

\section{考 察}

膵性腹水は1953年に Smith ${ }^{1 /}$ が初めて報告して以 
来，欧米では比較的多くの報告がされているが，本邦 では比較的稀な疾患で，1975年から1989年まての間に 清水ら によよって41例が報告され，1990年よりはわれ われが調べ得た範囲では，17例の報告があるのみで あった。

膵性腹水の発生機序としては,1）薄い壁をもつ脺仮

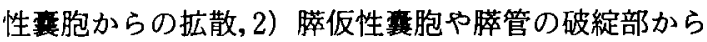
の流出，3）膵の壊死部からの漏出が考えられている. このうち主要なものは，膵仮性衰胞や膵管の破綻部か らの流出である。.さらに膵液の流出による病的変化を 来した腹膜が腹水を十分吸収できないことが膵性腹水 の原因であるとしている゙2.われわれの症例において も膵仮性裹胞よりの膵液の漏出が腹水の原因であっ た。また膵性腹水のほとんどが男性で, 基礎疾患の $80 \%$ 以上にアルコール性慢性膵炎が存在すると言われてい $ろ^{6}$. 本症例においても慢性萃炎の原因はアルコール であった。

臨床症状は高度の腹水貯留による腹部膨満などの非 特異的な消化器症状, それに伴う全身倦急感や体重減 少が主で233，急性膵炎時に見られるような腹膜炎症状 は認められなかった。これは漏出した膵液中の膵酵素 は十二指腸の enterokinaseによる活性化を受けず, proenzyme として存在しているため, 腹膜刺激症状が 少なく，また，このため周囲組織の炎症による被包化 が遅れることから大量の無痛性の腹水を呈するためと 考えられている781.

診断は 1 : 腹水中の高アミラーゼ（血清值を超え る), 高蛋白 $(<3.0 \mathrm{~g} / \mathrm{dl})$ を証明すること, 2 ：画像診 断により膵病変（慢性膵炎，仮性軎胞）の存在, 特に 内萃没漏の存在を証明することが必要であるとされて (る ${ }^{7)}$. しかし清水らの報告 ${ }^{6)}$ によと内膵液漏の証明 は困難で，この存在を術前に確認しえたのは $16 \%$ の であっだ).さらに通常膵管または仮性衰胞の破綻に よる萃液の流出が前方 (腹腔側) へ向かって生じると 膵性腹水を形成し，また，これが後方（後腹膜腔側） へ向かって生じると, 流出した萃液は抵抗の少ない大 動脈裂口，食道裂口を経て絘隔内に達し，さらに胸腔 内に破綻, 膵性胸水を形成するといわれている8”. われ われの症例では, 膵頭部の後腹膜腔側に形成された仮 性裹胞より, 腹膜側へ膵液が流出するという複雑な経 路をとったが, ERCP 後の腹部 CT 検査にて，その経 路が確認された。すなわち主脺管より注入された造影 剂は膵頭部後面の仮性亯胞より腹腔内へ漏出してい た。
膵性腹水の治療は, まず, 絶食, 高カロリー輸液, 穿刺による腹水の排除等保存的治療を行う。これは脺 の安静を保ち脺管破綻部からの膵液の漏出を自然治疮 させ,さらに腹水を除去することにより，癒着を促し， 破綻部を被覆させることを目的とするが，2〜6週間 で治捻傾向の見られないものに対しては外科的治療が 積極的に行われる ${ }^{2 \sim 4)}$. 術式の選択として, 本症のほと んどがその基礎疾患に慢性脺炎があることより，慢性 勝炎の術式の選択と同様に，良性疾患であることを考 慮して, 機能温存をはかりつつ根治性を追求する術式 を選択すべきである ${ }^{910)}$. われわれの症例では膵頭部 後面に仮性蛮胞を認めたため，切除するには脺頭十二 指腸切除が必要であったか，原疾患と術後の quality of life 考慮し, より安全で膵切除量の少ない術式を 選択することとした．さらに今回の症例では膵頭部後 面の仮性䧶胞を主脺管を経由して空腸内に確実にドレ ナージする必要があった。通常の膵管空腸側々吻合術 に伴う膵管切開では, 膵管切開部と仮生囊胞との交通 部を直線的に空腸内にドレナージ出来ないため, 脺頭 部において coring-out を施行, その部と仮性衰胞に十 分な交通のあることを確認し，膵管空腸側側吻合を施 行した。すなわち Frey の手術占を施行したのである. このことにより仮性葶胞を経由して腹腔内に漏出して いた膵液は，空腸内に確実にドレナージされ，膵性腹 水が改善された，尚，膵仮性襄胞より逆流する膵液， 腸液については，ドレーンによる瘦孔化の後, 腹圧に よる瘦孔閉鎖を考えていたが，仮生售胞内腔は，術後 数日で癒着により閉鎖されたようであった。

膵性腹水の原因が膵頭部にあり，保存的治療に抵抗 する場合，その手術方法の一つに，Frey の手術は，手 術侵襲も少なく膵液漏出部の確実なドレナージができ る術式として有効であると考えられた。

\section{結語}

アルコール性慢性膵炎に伴う膵性腹水の症例に, Freyの手術を施行し良好な結果を得たので, 若干の文 献的考察を加え報告した。

\section{文献}

1) Smith EB : Hemorrhagic ascites and hemothrax associated with benign pancreatic disease. Arch Surg 67: 52-56, 1953

2）内山哲史, 山本達人, 水田英司他：膀性腹水一本邦 報告例に見る実態一。肝・胆・脺 $16 ： 63-68$, 1988

3) Fernandez CL, Margarona E, Llovera J, et al : 
Pancreatic ascites. Hepato-Gastroenterol 40 : 150-154, 1993

4) 内山哲史, 平木桜夫, 飯塚徳男 他: 慢性膵炎と胸 水, 腹水. 肝 - 胆 - 膵 $20: 273-278,1990$

5) Frey CF, Smith GJ : Description and rationale of a new operation for chronic pancreatitis. Pancereas 2: 701-707, 1987

6) 清水直子, 棚橋 忍, 白子順子他：術前に脺菜胞破 綻部を証明しえた膵性腹水の 1 例. 日内会誌 81 ： $118-120,1992$
7）黒田 慧, 仙波大右, 永井秀雄他：脺性胸水, 腹水. 胆と脺 $7: 407-415,1986$

8) Cameron JL, Kieffer RS, Anderson WJ, et al : Internal pancreatic fistulas: Pancreatic ascites and pleural effusions. Ann Surg $184: 587-593$, 1976

9）田村勝洋, 中瀬 明：慢性膵炎の外科治療につい て. 島根医 7:985-991，1987

10）黑田 慧：慢性膵炎の外科治療一特に術式の選択 について一. 日消外会誌 $12: 657-663,1979$

\title{
A CASE OF PANCREATIC ASCITES SUCCESSFULLY TREATED BY FREY'S OPERATION
}

\author{
Takashi URATA, Takashi ASAKAWA and Shinji HIROOKA \\ Department of Surgery, Wakakusa Daiichi Hospital \\ Motohiro IMANO and Harumasa OYANAGI \\ Department of Surgey II, Kinki University School of Medicine
}

Pancreatic ascites is massive and chronic retention of ascites caused by benign pancreatic diseases. It is thought that in many cases this disease is caused by a formation of internal pancreatic fistula associated with chronic pancreatitis. This time we experienced a case of pancreatic ascites with alcoholic chronic pancreatitis. A 62-year-old man was found having massive ascites with high amylase and high protein. Endoscopic retrograde cholangiopancreatography (ERCP) revealed a portion which appeared to be pseudocyst and following abdominal CT showed intraabdominal leakage of a contrast medium. So the patient was diagnosed as pancreatic ascites. Conservative treatments including high caloric infusion therapy and centesis of ascites were ineffective. Frey's operation was carried out, with a successful outcome. 